\author{
JURNAL LAMPUHYANG \\ LEMBAGA PENJAMINAN MUTU \\ STKIP AGAMA HINDU AMLAPURA
}

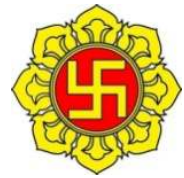

Volume 12 Nomor 2 Juli 2021

p-ISSN: 2087-0760; e-ISSN: 2745-5661

https://e-journal.stkip-amlapura.ac.id

\title{
Penggunaan Media Visual "POSTER BERGAMBAR" dalam Pembelajaran Bahasa Inggris untuk Anak Usia Dini
}

\author{
Luh Melin Udayanti \\ STKIP Agama Hindu Amlapura \\ melinuda@gmail.com
}

\begin{abstract}
Abstrak: Tujuan dari penelitian ini adalah untuk menganalisis tanggapan peserta didik terhadap penggunaan media visual berupa poster di kelas Pengajaran Bahasa Inggris. Penelitian berlangsung di sekolah dasar nomor 1 Pancasari, Bali. Sebanyak 25 siswa dari kelas empat berpartisipasi dalam penelitian ini. Siswa diminta menjawab beberapa pertanyaan tentang proses pembelajaran Bahasa Inggris dengan menggunakan poster. Mereka juga diajak untuk mendiskusikan tanggapan mereka satu sama lain. Peneliti memberikan kuesioner yang terdiri dari 4 pertanyaan tentang penggunaan poster dan kontribusinya terhadap pembelajaran mereka. Hasil penelitian menunjukkan bahwa penggunaan poster membantu siswa dalam proses belajar mandiri, membangun motivasi, dan membantu siswa lebih memahami bahasa Inggris daripada menggunakan buku teks serta memahami topik dengan lebih baik.
\end{abstract}

Kata Kunci : Media Visual, Poster, Anak Usia Dini

\begin{abstract}
The purpose of this study is to analyze the responses of young learners toward the use of visual media in the form of posters in an English Language Teaching class. The study took place in elementary school number 1 Pancasari, Bali. A total of 25 students of the fourth grade participated in the study. The students were asked to respond to several questions about the teaching process of English using posters. They were also encouraged to discuss their responses with each other. The researcher administered a questionnaire consisting of 4 questions about the use of the posters and its contribution to their learning. The results of the study showed that the use of the posters helped the students with their self-learning process, constructed their motivation, and helped them understand the English themselves better than using textbook as well as understand the topics better.
\end{abstract}

Key Words: Visual Media, Poster, Young Learner 


\section{PENDAHULUAN}

\subsection{Latar Belakang}

Belajar merupakan kegiatan yang membutuhkan konsentrasi.

Dalam proses pembelajaran, guru tidak lagi sekedar mentransfer pengetahuan, tetapi siswa itu sendiri harus membangun pengetahuan yang dikonstruksikannya sendiri (Hoover, 1996). Pengetahuan adalah sekumpulan fakta, konsep atau aturan yang digunakan untuk diterima dan diingat oleh peserta didik (Minnaert, 2006). Cummins, Bismilla, Chow, Giampapa, Cohen, Leoni, Sandhu, \& Sastri, (2005) menegaskan bahwa belajar adalah proses membangunkan pengetahuan dan mengkomunikasikan pengetahuan.

Anak-anak memiliki perkembangan kognitif aktif dalam masa belajar mereka dan itu meningkat seiring dengan perkembangan kemampuan mereka untuk berinteraksi dengan orang lain. Dalam konteks sistem pendidikan Indonesia, anak usia dini di sini merujuk pada siswa usia sekolah dasar, berkisar antara 6 hingga 12 tahun (Aisyah, Chandrawati, Tatminingsih, Novita, Setiawan, 2012). Alasan di balik keputusan untuk memulai pada usia ini karena anak-anak dianggap memiliki pengalaman literasi yang cukup dengan bahasa pertama (nasional) mereka. Mereka umumnya menjadi percaya diri dalam membaca dan menulis dalam bahasa pertama mereka.

Anak usia dini memiliki beberapa ciri yang harus diperhatikan oleh guru karena berbeda dengan orang dewasa. Salah satu ciri tersebut adalah anakusia dini merupakan pembelajar yang aktif (Piaget dalam Cameron, 2001). Sebagai pembelajar aktif, anak usia dini senang dilibatkan dalam proses pembelajaran. Itu karena mereka belajar sesuatu dari segala sesuatu di sekitar mereka secara lebih tidak langsung daripada secara langsung 
(Harmer, 2001). Sejalan dengan hal tersebut, Indra (2005) menyatakan bahwa pembelajaran anak usia dini yang efektif dipengaruhi oleh beberapa faktor, dua yang terpenting adalah: guru dan fasilitas.

Untuk mencapai tujuan pembelajaran bahasa Inggris bagi anak didik, guru diharapkan dapat mengembangkan media pembelajaran dan kegiatan pembelajaran agar menyenangkan dan menarik. Anak-anak biasanya tertarik untuk belajar dengan sesuatu yang divisualisasikan dalam bentuk warna-warni dan konkret. Penggunaan media visual dapat memperkuat pemahaman, terutama proses abstrak yang sulit dibayangkan dalam pikirannya (Perry, 2013). Artinya siswa khususnya pada tahap pembelajar muda akan merasakan kesenangan dan cara belajar yang menyenangkan ketika mereka dapat melihat animasi melalui prosesnya, mereka mungkin dapat mempelajarinya dengan lebih mudah daripada hanya sekedar mendengar penjelasan guru. Salah satu alasan penelitian ini dilakukan adalah untuk mengkaji penggunaan media visual berupa poster dalam pembelajaran bahasa Inggris bagi anak usia dini. Bagian berikut menyajikan tinjauan singkat literatur diikuti dengan metodologi yang digunakan untuk penelitian ini. Kemudian analisis data dan hasil dilaporkan dan akhirnya disediakan diskusi umum.

\subsection{Rumusan Masalah}

Rumusan masalah dalam artikel ini adalah: Bagaimanakah tanggapan anak usia dini terhadap penggunaan media poster bergambar dalam pembelajaran Bahasa Inggris?

\subsection{Tujuan Penelitian}

Sejalan dengan rumusan masalah tersebut, tujuan yang ingin dicapai dalam penelitian ini adalah untuk mendeskripsikan tanggapan anak usia dini terhadap penggunaan media poster bergambar dalam pembelajaran Bahasa Inggris.

\subsection{Manfaat Penelitian}

Penelitian ini bermanfaat secara teoretis untuk pengembangan media pembelajaran bahasa Inggris yang relevan digunakan untuk anak usia dini. 
Sementara itu, secara praktis hasil penelitian ini bermanfaat bagi anak usia dini, guru, dan orang tua dalam rangka pencapaian kualitas pembelajaran bahasa yang efektif dalam tumbuh kembang anak.

\section{TINJAUAN PUSTAKA}

Poster bergambar dalam pendidikan sebagai objek dekoratif namun hanya sedikit yang menyadari potensi pendidikan dari poster tersebut. Poster adalah media pembelajaran yang menarik dan penuh warna yang dapat meningkatkan lingkungan belajar (Musser dan Osa, 2004). Poster telah dikenal sebagai barang kolektor karena berbagai alasan (Jennings, 2012). Poster memiliki nilai instruksional. Pendidik menggunakan poster sebagai alat pengajaran dalam Seni Bahasa dan Seni visual. Tidak hanya sebagai referensi dalam sekilas vogues masa lalu, tetapi juga dari sudut pandang penataan komunikasi yang efektif dan ringkas (Kelsch \& Werremeyer, 2011). Menurut Jensen, "mata kita mencatat sekitar 36.000 gambar visual per jam, sedangkan retina sendiri memasok $40 \%$ dari semua serabut saraf yang terhubung ke otak; 90\% masukan sensorik otak berasal dari sumber visual (Jensen, 2000). Para peneliti melaporkan bahwa indra visual bertanggung jawab atas $90 \%$ stimulasi otak dan penglihatan serta memori visual menempati hingga dua pertiga otak (International Quality Visual Education, 2003). Karena penyerapan pengetahuan adalah kunci sukses dalam setiap sistem pendidikan, guru harus memiliki koleksi yang kaya akan materi visual. Anak-anak berbeda dari pelajar dewasa dalam banyak hal terutama dalam memperoleh informasi. Terutama anak-anak mencari rangsangan lingkungan yang mendorong perkembangan intelektual mereka seperti representasi objek. Carney dan Levin (2002) juga melaporkan bahwa gambar tidak hanya meningkatkan proses membaca-untuk-belajar, tetapi mereka juga menunjukkan bahwa gambar-gambar ini harus dipilih dengan baik atau dibuat dengan baik. Sementara banyak dari buku teks baru yang banyak bergambar, buku teks tidak dapat menggantikan poster pembelajaran sebagai media visual dalam pengajaran 
bahasa Inggris. Osa dan Musser pada tahun 2004 mengusulkan beberapa jenis tujuan pembelajaran yang poster dapat dicapai dengan penggunaan poster dalam proses pembelajaran; mengilustrasikan konsep atau hal, mendemonstrasikan proses, membedakan antara hal-hal serupa dan menangkap minat serta merangsang emosi.

\section{METODE PENELITIAN}

Penelitian ini berlangsung di kelas IV SDN 1 Pancasari, Buleleng-Bali. Tujuan dari penelitian ini adalah untuk mengetahui tanggapan peserta didik tentang penggunaan poster sebagai media visual secara lebih spesifik apakah poster bermanfaat untuk digunakan sebagai media visual lebih baik daripada buku teks dalam proses belajar mengajar. Pesertanya adalah siswa kelas IV yang terdiri dari 25 siswa. Mata pelajaran bahasa Inggris diimplementasikan sebagai salah satu muatan lokal kurikulum 2013 di Indonesia yang diajarkan seminggu sekali dalam waktu 70 menit dalam setiap pertemuan.

Penelitian ini merupakan penelitian deskriptif. Penelitian ini dilakukan untuk mendeskripsikan penggunaan media visual pada siswa kelas IV SDN 1 Pancasari Buleleng-Bali. Penelitian ini dilakukan di sebuah sekolah yang terletak di daerah terpencil yang memiliki fasilitas kelistrikan yang terbatas untuk mendukung proses pembelajaran. Sekolah telah menerapkan bahasa Inggris di kelas empat sebagai mata pelajaran muatan lokal pada kurikulum 2013. Ada tiga instrumen yang digunakan dalam penelitian ini. Mereka adalah lembar observasi dan kuisioner, serta pedoman wawancara. Data yang diperoleh dari observasi kelas dikategorikan berdasarkan aktivitas selama kegiatan kelas dalam menggunakan media visual dan mengecek dengan teori yang sesuai tentang penggunaan media visual. Data yang diperoleh dari angket siswa dihitung dan dideskripsikan dalam persentase. Data yang dikumpulkan melalui wawancara digunakan untuk memperoleh data yang tidak dapat diperoleh melalui instrumen lain.

\section{HASIL DAN PEMBAHASAN}

Observasi dilakukan untuk mengetahui reaksi siswa selama implementasi poster di kelas. Hal 
tersebut dilakukan oleh peneliti dengan mengamati video dan foto yang diambil selama pelaksanaan poster. Berdasarkan video dan foto, diketahui bahwa siswa senang belajar bahasa Inggris dengan menggunakan media visual berupa poster. Hal itu didukung dengan perhatian penuh mereka terhadap poster selama guru membaca kata-kata yang tertera di poster. Mereka mendengarkan dengan cermat guru dan secara aktif menjawab pertanyaan dan membaca kata-kata di poster. Penggunaan media visual berupa poster juga mudah diterapkan oleh siswa. Beberapa menit setelah guru membimbing siswa untuk berbicara dengan apa yang mereka baca di poster, dua siswa muncul untuk mengungkapkan apa yang mereka ingat di poster sebelumnya. Selain itu, penggunaan media visual berupa poster dapat membantu siswa dalam memahami pelajaran yang diberikan. Hal itu ditunjukkan dengan kemampuan siswa dalam menjawab soal-soal yang diberikan oleh guru dan beberapa soal yang berkaitan dengan topik yang dibahas pada poster.
Instrumen selanjutnya yang digunakan adalah item angket siswa. Angket digunakan untuk mengetahui respon siswa terhadap penerapan poster di kelas. Ada empat item angket yang dibagikan kepada dua puluh lima siswa kelas IV SDN 1 Pancasari.

Materi tersebut terkait dengan perasaan siswa terhadap poster, proses pembelajaran menggunakan poster, penggunaan poster dalam membantu siswa memahami pelajaran, dan penggunaan poster dalam memotivasi mereka untuk belajar bahasa Inggris. Item pertama dari angket siswa adalah tentang perasaan siswa dalam belajar bahasa Inggris dengan menggunakan poster. Berdasarkan hasil angket terhadap dua puluh lima siswa ditemukan bahwa $68,00 \%$ merasa senang belajar bahasa Inggris dengan menggunakan poster dan $28,00 \%$ menyatakan sangat senang. Dari hasil tersebut dapat disimpulkan bahwa sebagian besar siswa senang belajar bahasa Inggris dengan menggunakan media visual berupa poster. Senada dengan item pertama, item kedua juga menunjukkan hasil yang serupa. Dari dua puluh lima siswa, 76,00\% menyatakan 
bahwa proses pembelajaran bahasa Inggris dengan menggunakan big book sangat mudah dilakukan dan $24,00 \%$ menyatakan mudah. Item selanjutnya ditanyakan tentang penggunaan poster dalam membantu siswa memahami pelajaran. Dari dua puluh lima siswa, sebanyak $80,00 \%$ menyatakan poster sangat membantu dan $20,00 \%$ menyatakan poster bermanfaat. Penggunaan poster dalam memotivasi siswa untuk belajar bahasa Inggris menjadi item kuesioner siswa berikutnya.

Berdasarkan hasil penelitian dari dua puluh lima siswa ditemukan bahwa hanya $64,00 \%$ yang menyatakan termotivasi dan $36,00 \%$ yang menyatakan bahwa poster tersebut memotivasi mereka untuk belajar bahasa Inggris. Beberapa penelitian telah membuktikan penggunaan poster dalam dunia pendidikan. Sebuah penelitian eksperimental berjudul "Menggunakan Poster sebagai Alat Pengajaran dalam Mengelola Kelas Besar" juga berhasil mempromosikan alat yang efektif untuk mengajar, menilai, dan mengelola kelas besar di Penyelenggaraan Pendidikan Tinggi di Nigeria (Aduradola \& Ale, 2013).
Kelsch dan Werremeyer pada tahun 2012 juga melakukan penelitian dengan judul "Proyek Poster Penekanan Kesehatan Masyarakat dalam Kurikulum Farmasi”. Penelitian tersebut juga berhasil meningkatkan motivasi belajar siswa di kelas. Studi Kasus Penggunaan Media Visual dalam Bahasa Inggris juga dilakukan oleh Syandri (2015) sebagai sarana untuk menarik perhatian siswa, memberi semangat siswa untuk bertanya, dan membantu guru menjelaskan materi. Hasilnya, semua siswa bersikap positif terhadap penggunaan media visual dalam proses pembelajaran karena mereka dapat memahami materi dengan lebih baik dan tidak bosan selama proses pembelajaran. Ada banyak hal lain yang harus dilakukan di kelas untuk memastikan bahwa siswa berhasil di kelas. Tidak perlu memberikan pekerjaan rumah pada tahap ini tetapi guru perlu mengembangkan kegiatan dan materi pembelajaran agar siswa dapat melihat secara visual apa yang telah dipelajari dan bagaimana mereka melakukannya. Tinjau terus dan hindari memperkenalkan terlalu banyak kosakata baru untuk pelajar muda. Siswa pada tahap ini mungkin tidak mengingat materi 
dari satu hari ke hari berikutnya sehingga pengulangan menjadi penting. Keberhasilan proses pembelajaran ditentukan dari kualitas sumber daya yang mendukung guru.

Dalam aktivitas pembelajaran seperti ini guru mengoptimalkan perannya sebagai fasilitator bagi siswa dengan menfasilitasi aktivitas belajar bahasa siswa melalui penggunaan media poster bergambar. Media poster bergambar ini memiliki ketertarikan tersendiri bagi pembelajar bahasa usia dini. Dengan timbulnya ketertarikan melalui media-media poster bergambar yang digunakan, anak akan merasa senang belajar. Dengan tumbuhnya perasaan senang tersebut, anak akan lebih mudah menyerap materi pelajaran bahasa Inggris yang disampaikan oleh guru. Terlebih lagi dengan visualisasi dalam bentuk gambar-gambar yang tersaji dalam media poster tersebut dapat menambah ingatan siswa.

Menurut Jensen, sekitar 36.000 gambar visual per jam dapat kita catat di ingatan kita masing-masing, sedangkan retina sendiri memasok $40 \%$ dari semua serabut saraf yang terhubung ke otak;
$90 \%$ masukan sensorik otak berasal dari sumber visual (Jensen, 2000). Para peneliti melaporkan bahwa indra visual bertanggung jawab atas $90 \%$ stimulasi otak dan penglihatan serta memori visual menempati hingga dua pertiga otak (International Quality Visual Education, 2003). Terlebih lagi untuk anak usia dini yang tergolong kemampuan visualnya sangat membantu dalam kegiatan pembelajaran karena berada pada fase belajar dari hal-hal yang konkret.

Penyerapan pengetahuan adalah kunci sukses dalam setiap sistem pendidikan, guru harus memiliki koleksi yang kaya akan materi visual. Anak-anak berbeda dari pelajar dewasa dalam banyak hal terutama dalam memperoleh informasi. Terutama anak-anak mencari rangsangan lingkungan yang mendorong perkembangan intelektual mereka seperti representasi objek. Carney dan Levin (2002) juga melaporkan bahwa gambar tidak hanya meningkatkan proses membaca-untuk-belajar, tetapi mereka juga menunjukkan bahwa gambar-gambar ini harus dipilih dengan baik atau dibuat dengan baik. 


\section{PENUTUP}

\subsection{Simpulan}

Singkatnya, temuan penelitian ini mengungkapkan bahwa penggunaan poster dalam pengajaran bahasa Inggris untuk pelajar muda dapat berdampak positif pada hasil belajar. Visualisasi dalam bentuk poster dapat membantu siswa memahami informasi yang kompleks. Gambar visual yang dirancang dengan baik dapat menghasilkan pengalaman belajar yang jauh lebih kuat dan berkesan daripada sekadar verbal atau tekstual. Siswa di kelas reguler perlu melihat informasi untuk mempelajarinya. Media visual membantu siswa atau semua usia mengelola tujuan pembelajaran dengan lebih baik dan mencapai keberhasilan akademis.

Penelitian ini bukannya tanpa batasan. Penelitian masa depan dapat membahas beberapa bidang. Pertama-tama, penelitian ini hanya melibatkan sasaran anak usia dini. Penelitian selanjutnya hendaknya melibatkan kelompok siswa yang berbeda dan pengalaman belajarnya dengan media visual hingga persepsi yang berbeda tentang penggunaan poster sebagai salah satu media visual.

\subsection{Saran}

Melalui penelitian ini disampaikan saran kepada pihak-pihak sebagai berikut.

1) Siswa diharapkan meningkatkan kemampuan berbahasa melalui media-media yang menarik.

2) Guru hendaknya menjadi fasilitator siswa dalam pembelajaran bahasa Inggris melalui beragam media.

3) Para orang tua hendaknya mengontrol pemerolehan bahasa kedua sang anak agar dapat berkembang secara optimal.

\section{DAFTAR PUSTAKA}

Aisyah, Chandrawati, T., Tatminingsih, S., Novita, D., Setiawan,D. 2012. Perkembangan dan Konsep Dasar Pengembangan Anak Usia Dini. Banten: Universitas Terbuka Aduradola, R.R.,Ale, A.I.B. 2013. The Power of Student's Involvement: Using Posters as Teaching Tools in Managing Large Classes. Journal of English for Specific Purposes World, Vol.14, No. 40, ISSN 1682-3257. 
Carney, R.N and Levin, J.R. 2002. 'Pictorical Illustrations still Improve students' Learning from Text. Journal of Educational Psychology, Vol. 14, no. 1 .

Cummins, J., Bismilla, V., Chow, P., Giampapa, F., Cohen, S., Leoni, L., Sandhu, P., \& Sastri, P. 2005. Affirming identity in multilingual classrooms. Journal of Educational Leadership, 63, 38-43

Hoover, W. A. 1996. The practice implications of constructivism. The practice implications of constructivism. SEDL advancing research, improving education. Retrieved June 27, 2010, from http://www.sedl.org/pubs/sedletter/ v09n03/practice.html

Jennings,D. 2012. An Introduction to Effective Poster Design and Production. UCD Teaching And Learning: Dublin

Kelsch,M.P.,Werremeyer,A.B. 2011. Poster Project to Emphasize Public
Health in the Pharmacy Curriculum. American Journal of Pharmaceutical Education. Vol.34, No.2.

Minnaert, 2006. Current philosophy and practice in ESL/EFL reading education: An analysis. Retrieved from ERIC database. (ED482577)

Osa, O.J.,Musser, R.L. 2004. The Role of Posters in Teacher Education Programs. Journal of Education Libraries. Vol.27, No.1, Pennsylvania State University Syandri, G. 2015. A Case Study on the Used of Visual Media in English Instructional Process at State Islamic Secondary School 1 Malang. Journal of Research \& Method in Education. Vol. 5, No. 4 46-56 